\title{
Neuroendocrine-like prostate cancer cells: neuroendocrine transdifferentiation of prostate adenocarcinoma cells
}

\author{
Ta-Chun Yuan ${ }^{1}$, Suresh Veeramani ${ }^{1}$ and Ming-Fong Lin ${ }^{1,2}$
}

\author{
${ }^{1}$ Department of Biochemistry and Molecular Biology, College of Medicine, University of Nebraska Medical Center, 985870 Nebraska \\ Medical Center, Omaha, Nebraska 68198-5870, USA \\ ${ }^{2}$ Eppley Institute for Cancer Research, University of Nebraska Medical Center, Omaha, Nebraska 68198, USA \\ (Correspondence should be addressed to M-F Lin; Email: mlin@unmc.edu)
}

\begin{abstract}
Neuroendocrine (NE) cells represent a minor cell population in the epithelial compartment of normal prostate glands and may play a role in regulating the growth and differentiation of normal prostate epithelia. In prostate tumor lesions, the population of NE-like cells, i.e., cells exhibiting NE phenotypes and expressing NE markers, is increased that correlates with tumor progression, poor prognosis, and the androgen-independent state. However, the origin of those NE-like cells in prostate cancer $(\mathrm{PCa})$ lesions and the underlying molecular mechanism of enrichment remain an enigma. In this review, we focus on discussing the distinction between NE-like PCa and normal NE cells, the potential origin of NE-like PCa cells, and in vitro and in vivo studies related to the molecular mechanism of NE transdifferentiation of PCa cells. The data together suggest that PCa cells undergo a transdifferentiation process to become NE-like cells, which acquire the NE phenotype and express NE markers. Thus, we propose that those NE-like cells in PCa lesions were originated from cancerous epithelial cells, but not from normal NE cells, and should be defined as 'NE-like PCa cells'. We further describe the biochemical properties of newly established, stable NE-like lymph node carcinoma of the prostate (LNCaP) cell lines, transdifferentiated from androgen-sensitive $\mathrm{LNCaP}$ cells under androgen-deprived conditions. Knowledge of understanding NE-like PCa cells will help us to explore new therapeutic strategies for treating $\mathrm{PCa}$.
\end{abstract}

Endocrine-Related Cancer (2007) 14 531-547

\section{Introduction}

Neuroendocrine (NE) cells are the third cell type in the epithelial compartment of normal prostate glands in addition to basal and secretory epithelial cells (Abrahamsson 1999). Though prostatic NE cells were described decades ago, their functional roles in prostate, especially in prostate cancer $(\mathrm{PCa})$ progression, have received attention only recently. In normal prostate, NE cells are apparently involved in regulating epithelial cell growth and differentiation in an androgen-independent (AI) manner. In prostate carcinoma, the NE cell population, as characterized by the expression of NE markers, in tumor foci is increased, which evidently correlates with tumor progression, poor prognosis, and the hormonerefractory stage. The role of $\mathrm{NE}$ cells in $\mathrm{PCa}$ progression is suggested by the fact that those cells express and secrete a variety of neuropeptides which have mitogenic effects on adjacent cancer cells and thus can contribute to the AI proliferation of $\mathrm{PCa}$ cells (di Sant'Agnese 1992, 1998, di Sant'Agnese \& Cockett 1996). Further studies also show that NE differentiation is found in the metastatic lesion and significantly associated with the mortality of $\mathrm{PCa}$ patients (Cheville et al. 2002, Roudier et al. 2003). Although the origin of $\mathrm{NE}$ cells and the molecular mechanism of $\mathrm{NE}$ cell enrichment during $\mathrm{PCa}$ progression are not fully understood, accumulated evidence including in vitro cell culture, in vivo animal model, and clinical sample analyses together indicate that $\mathrm{PCa}$ cells can undergo a transdifferentiation process to become NE-like cells, which 
acquire the NE phenotype and express NE markers. Thus, we propose to define those NE-like cells in $\mathrm{PCa}$ lesions as 'NE-like PCa cells'.

In this review, we focus our discussion on the potential origin of NE-like PCa cells and the molecular mechanism of NE transdifferentiation. In the first section, we discuss the differences between NE-like $\mathrm{PCa}$ and normal NE cells in their biochemical properties and origins. In the second section, we present data from in vitro and in vivo studies suggesting the multipathway of $\mathrm{NE}$ transdifferentiation occurring in $\mathrm{PCa}$ cells and discuss their underlying molecular mechanisms. In the final section, we describe the biochemical properties of newly established NE-like LNCaP stable subclone cells which represent a useful model mimicking clinical NE-like cells in prostate tumors. Knowledge of NE-like $\mathrm{PCa}$ cells will provide us with new insights for developing novel therapeutic strategies for treating PCa.

\section{NE-like PCa versus normal NE cells Differences in biochemical characteristics between NE-like PCa and normal NE cells}

Several reviews have extensively described the characterizations of prostatic NE cells and their functions in both physiological and pathological states (di Sant'Agnese 1992, 1998, di Sant'Agnese \& Cockett 1996, Abrahamsson 1999, Sciarra et al. 2003, Vashchenko \& Abrahamsson 2005). However, an important question of whether NE-like PCa cells differ from normal NE cells is less addressed. While several studies in $\mathrm{PCa}$ archival specimens have shown that NE-like PCa cells share similar biochemical properties with NE cells in the normal prostate, including the expression of NE markers as well as the lack of AR and PSA, these reports also suggest several differences existing between NE-like PCa and normal NE cells (Table 1; Abrahamsson 1999, Vashchenko \& Abrahamsson 2005). First, immunohistochemical studies have shown that NE cells in the normal prostate gland express cytokeratin 5 (K5), a basal cell marker (Schalken \& van Leenders 2003, Hudson 2004); while NE-like PCa cells exhibit characteristics of luminal secretory cells by expressing prostatic acid phosphatase (PAcP; Huang et al. 2006) and K18, a luminal cellspecific cytokeratin (van Bokhoven et al. 2003, Vashchenko \& Abrahamsson 2005). Huang et al. (2006) further showed that CgA-positive NE-like cells in $\mathrm{PCa}$ archival specimens are positively stained with antibodies (Abs) against luminal secretory cell-associated cytokeratins; while they are negative for staining with Abs against basal cell markers, including high molecular weight cytokeratin and p63 (Wojno \&
Table 1 Comparison of normal neuroendocrine (NE) and $\mathrm{NE}$-like prostate cancer (PCa) cells in prostate

Similarities
Lack of AR and PSA expression
Autocrine/paracrine effects
Non/low-proliferative activity
Neuron-like morphology
Expression of NE markers
NSE
CgA
CgB
Serotonin
PTHrP
NT
Bombesin
Dissimilarities (normal NE versus NE-like PCa cells)
Expression of basal cell markers versus luminal secretory cell
markers
Non-aggressive versus highly aggressive
No Bcl-2 expression versus Elevated Bcl-2 expression
No AMACR expression versus AMACR expression

NSE, neuron-specific enolase; CgA, chromogranin A; CgB, chromogranin B; PTHrP, parathyroid hormone-related protein; NT, neurotensin; Bcl-2, B cell lymphoma protein 2; AMACR, $\alpha$-methylacyl-CoA racemase.

a Some reports show no neuron-like phenotype, i.e., without processing, in NE-like PCa cells.

Epstein 1995, Signoretti et al. 2000). Secondly, compared with normal NE cells with non-proliferating and non-tumorigenic activities, NE-like PCa cells, such as small cell carcinoma cells being completely $\mathrm{NE}$ differentiated (Yao et al. 2006), are highly aggressive and exhibit tumorigenic activity (Oesterling et al. 1992). Thirdly, while NE cells from normal prostate and benign prostatic hyperplasia do not express anti-apoptotic protein $\mathrm{B}$ cell lymphoma protein 2 (Bcl-2) (Xue et al. 1997), studies in archival PCa samples show a correlative relationship between the expression levels of Bcl-2 and neuron-specific enolase (NSE; Segal et al. 1994). Fourthly, $\alpha$-methylacyl-CoA racemase (AMACR), an enzyme involved in the $\beta$-oxidation of fatty acids, is only expressed in NE-like PCa cells and non-NE prostate tumor cells but not in normal prostatic cells including NE cells (Huang et al. 2006), suggesting the close linkage between NE-like $\mathrm{PCa}$ and prostate carcinoma cells. Finally, histological studies have clearly shown that normal NE cells exhibit two distinct morphologies which have a complex appearance with irregular dendrite-like processes extending between adjacent epithelial cells (di Sant'Agnese 1992), while some NE-like PCa cells may lack the typically neuron-like processes and are morphologically similar to the surrounding carcinoma cells (Xing et al. 2001). These data together suggest that NE-like PCa cells are clearly distinguished from NE cells in the normal prostate. 


\section{Origin of NE-like PCa versus normal NE cells}

The distinctions between NE-like PCa and normal NE cells may be attributed to their origins. As shown in Fig. 1, results of studies indicate that normal NE cells, as basal and luminal epithelial cells, are originated from stem cells in the basal layer (Hudson 2004, Long et al. 2005). It is also possible that normal NE cells represent an independent cell lineage from the neurogenic origin, differing from secretory and basal cells (Aumuller et al. 1999). Thus, the origin of NE cells in normal prostate glands requires further investigations.

Similarly, the origin of NE-like PCa cells remains controversial. It is proposed that NE-like $\mathrm{PCa}$ cells share the same origin with normal NE cells and are differentiated from the intermediate stem cells (Bonkhoff et al. 1995, Bonkhoff 1998). The differentiation processes of those stem cells may be aberrantly regulated under pathological conditions like androgen ablation, resulting in an abnormally increased NE cell population. Although this stem cell-based hypothesis is attractive, it requires further validation. Alternatively, accumulated evidence suggests that adenocarcinoma cells can undergo a transdifferentiation process to become NE-like cells, which acquire a similar phenotype to normal NE cells and express several $\mathrm{NE}$ markers. Importantly, they still retain some epithelial characteristics (Fig. 1; Vashchenko \& Abrahamsson 2005). This notion is supported by the observations that NCI-H660 and PSK-1 cells, two human prostatic small cell carcinoma cell lines, express $\mathrm{K} 8 / 18$ of luminal cell markers, but not K5/14 of basal cell markers (van Bokhoven et al. 2003). Furthermore, Bcl-2 expression is found in all specimens examined for prostatic small cell carcinoma $(18 / 18 ; 100 \%)$, whereas its expression is observed in two out of ten cases $(20 \%)$ of prostate adenocarcinoma (Yao et al. 2006) and no expression in normal NE cells (Xue et al. 1997), which suggests the correlative relationship of NE-like PCa cells and adenocarcinoma cells. In addition, NE differentiation can be seen in the bone metastatic lesion but not within the primary tumor foci, suggesting the occurrence of transdifferentiation process in metastatic $\mathrm{PCa}$ cells (Cheville et al. 2002, Roudier et al. 2003). Importantly, results of genetic analyses on clinical archival specimens further reveal that NE-like PCa cells share essentially identical allelic profiles with non-NE PCa cells, but not that of normal prostatic epithelium or normal NE cells (Sauer et al. 2006). These results collectively provide the evidence that NE-like PCa cells are originated from cancerous luminal epithelial cells, which undergo a transdifferentiation process (Fig. 1), and thus these cells should be defined as 'NE-like PCa cells', but not 'NE cells'.

\section{Multipathways involved in NE trans- differentiation of PCa cells}

\section{Androgen depletion-induced NE differentiation}

Androgen ablation therapy is the main option for treating metastatic PCa; however, androgen withdrawal also contributes to increased $\mathrm{NE}$

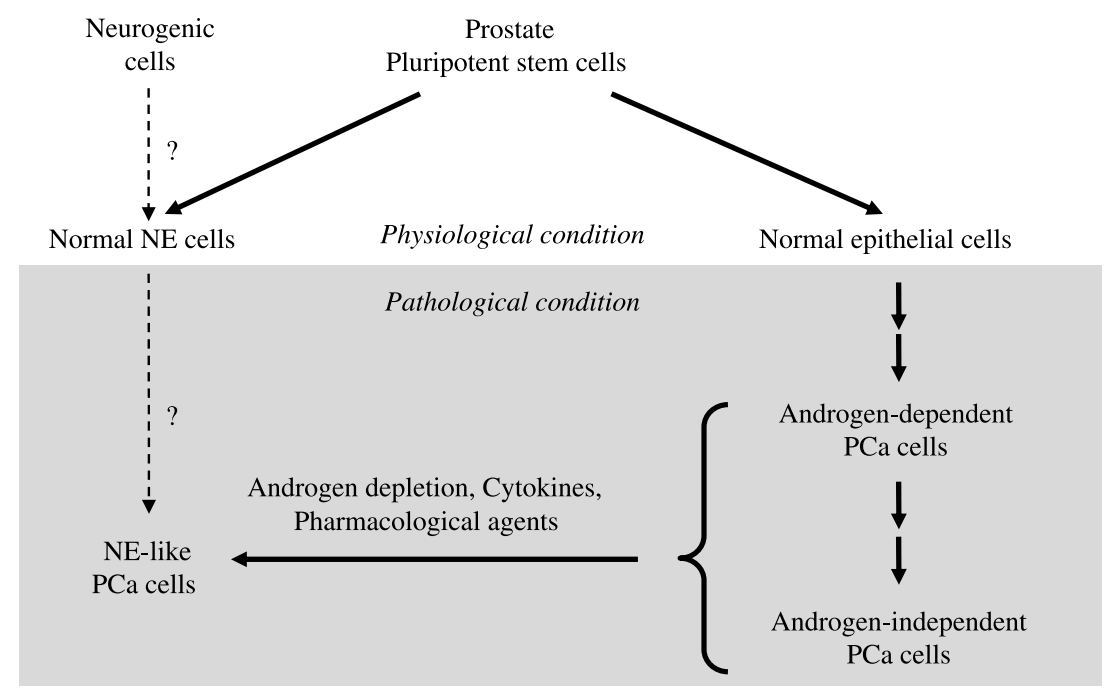

Figure 1 Proposed model of the origin(s) of NE-like PCa cells. 
differentiation in PCa (Ismail et al. 2002). It has been shown that patients who had received a longer course of androgen ablation therapy would have higher levels of NE differentiation. Ito et al. (2001) reported that in archival specimens from 137 PCa patients, $70.5 \%$ of 68 patients who had received hormonal therapy for more than 13 months exhibited NE differentiation, higher than $44 \%$ of 25 patients with hormonal therapy less than 12 months and $31.8 \%$ in 44 patients without therapy. A similar result was also shown in Hirano et al. (2004) study, which supports the notion that androgen ablation therapy increases NE differentiation of PCa cells.

To support the observations in clinical specimens, androgen withdrawal-induced NE differentiation of $\mathrm{PCa}$ cells is also seen in in vitro cell culture (Table 2) and in vivo animal model (Table 3) studies. The initial study revealed that androgensensitive (AS) LNCaP cells exhibit the capability of being transdifferentiated into an NE-like phenotype in response to androgen deprivation (Shen et al. 1997). Our data further showed that androgenreduced media can induce $\mathrm{NE}$ transdifferentiation of AS LNCaP cells, and these cells acquire the neuronal phenotype and express multiple NE markers, including NSE, CgA, gastrin, and neurotensin (Zelivianski et al. 2001, Yuan et al. 2006). This NE transdifferentiation induced by steroidreduced (SR) medium is reversed by the addition of DHT. Conversely, Casodex, an androgen antagonist, can compete out DHT effect and restore NE transdifferentiation. These results suggest that androgen-activated AR signaling suppresses NE differentiation. This notion is supported by the observation that knockdown of AR in AS LNCaP cells induces $\mathrm{NE}$ transdifferentiation, indicated by acquiring NE-like morphology and expressing NE markers (Wright et al. 2003).

Studies on in vivo animal models validate in vitro observations that castration of mice bearing AS PC-295 or PC-310 xenograft tumors promotes their NE differentiation, indicated by the elevated expression of NE markers (Jongsma et al. 1999, 2000). Similar results were also observed in castrated animals bearing xenografts of AS LNCaP (Burchardt et al. 1999) and CWR22 cells (Huss et al. 2004) as well as castrated TRAMP mice (Kaplan-Lefko et al. 2003). Consistent to clinical observations, data from in vitro and in vivo studies collectively support the notion that androgen depletion induces transdifferentiation of AS adenocarcinoma cells to become NE-like cells in $\mathrm{PCa}$ lesions.

\section{Mechanisms of androgen depletion-induced NE differentiation}

Receptor protein tyrosine phosphatase $\alpha$ (RPTP $\alpha)$ mediated signal pathway

RPTP $\alpha$ is a member of the transmembrane subfamily of PTPs and is widely expressed in mammalian tissues (Sap et al. 1990). In addition to the regulation of integrin signaling and potassium channel activity, RPTP $\alpha$ plays a critical role in neuronal differentiation (Pallen 2003). In AS LNCaP cells, the expression of RPTP $\alpha$ at both mRNA and protein levels is upregulated by androgen depletion, correlating with NE differentiation and NSE expression (Zelivianski et al. 2000, 2001). Furthermore, addition of androgens abolishes steroid depletion-induced RPTP $\alpha$ elevation, while Casodex can compete out androgen effects and restores RPTP $\alpha$ as well as NSE expression (Zhang et al. 2003). Further studies show that even in the regular culture condition containing androgenic activity, increased expression of RPTP $\alpha$ by cDNA transfection in AS LNCaP cells results in elevated levels of multiple NE markers, including NSE, chromogranin A $(\mathrm{CgA}), \mathrm{CgB}$, parathyroid hormone-related protein (PTHrP), and NT as well as acquired NE-like phenotype, suggesting a role of RPTP $\alpha$ in NE differentiation of AS PCa cells (Zhang et al. 2003, Yuan et al. 2006).

The molecular mechanism of RPTP $\alpha$-induced NE differentiation in AS PCa cells is closely associated with the activation of c-Src and ERK/MAPK (Zhang et al. 2003, Yuan et al. 2006). This notion is supported by observations that elevated RPTP $\alpha$ expression in LNCaP cells leads to c-Src activation, while the expression of Y789F-RPTP $\alpha$, a mutant of RPTP $\alpha$ which is devoid of interaction with c-Src, does not have an effect on c-Src activation and fails to induce NE marker expression as well as NE-like morphology (Yuan et al. 2006). Similarly, increased RPTP $\alpha$ expression in LNCaP cells also leads to ERK/ MAPK activation, correlating with elevated expression of multiple NE markers, while this RPTP $\alpha$-effect is abolished by PD98059, an MEK inhibitor (Zhang et al. 2003, Yuan et al. 2006). Importantly, PP2, an inhibitor of c-Src family kinases, can effectively abolish RPTP $\alpha$-induced ERK/MAPK activation as well as NE marker expression, and thus blocks SR medium-induced NE-like morphology in LNCaP cells (Yuan et al. 2006). These results collectively suggest that in androgen depletion condition, RPTP $\alpha$ is elevated and constitutively activates the c-Src-MEK-ERK/MAPK signal pathway, 
Table 2 In vitro studies of neuroendocrine (NE) differentiation of prostate cancer (PCa) cells

\begin{tabular}{|c|c|c|c|c|c|c|c|c|c|}
\hline Induction & Cell types & $\begin{array}{l}\text { NE-like } \\
\text { morphology }\end{array}$ & $\begin{array}{l}\text { Growth } \\
\text { arrest }\end{array}$ & $\begin{array}{l}\text { Marker } \\
\text { expression }\end{array}$ & $\begin{array}{l}\text { PSA/AR } \\
\text { expression }\end{array}$ & $\begin{array}{l}\text { Biological } \\
\text { phenotypes }\end{array}$ & $\begin{array}{l}\text { Paracrine } \\
\text { (CM) effects }\end{array}$ & $\mathrm{R} / \mathrm{IR}$ & References \\
\hline \multicolumn{10}{|c|}{ Androgen depletion } \\
\hline \multirow[t]{6}{*}{ SR medium } & LNCaP & Yes & Yes & $\begin{array}{l}\text { NSE/S- } \\
\text { 100/Bombesin }\end{array}$ & $\begin{array}{c}\text { Decreased } \\
\text { PSA/AR }\end{array}$ & ND & ND & $\mathrm{R}$ & Shen et al. (1997) \\
\hline & LNCaP (C-33) & Yes & ND & NSE/CgA/GS/NT & Decreased PSA & ND & ND & ND & $\begin{array}{l}\text { Zelivianski et al. } \\
\text { (2001) }\end{array}$ \\
\hline & LNCaP (C-81) & ND & ND & No effect & Decreased PSA & ND & ND & ND & \\
\hline & LNCaP (C-33) & Yes & Yes & NSE & ND & ND & ND & ND & Zhang et al. (2003) \\
\hline & LNCaP & ND & ND & NSE/CgA & ND & ND & ND & ND & Yang et al. (2005) \\
\hline & LNCaP & ND & ND & NSE & ND & ND & ND & ND & $\begin{array}{l}\text { Burchardt et al. } \\
\text { (1999) }\end{array}$ \\
\hline \multicolumn{10}{|l|}{ cAMP-related } \\
\hline \multirow[t]{2}{*}{ db-cAMP } & LNCaP (C-33) & Yes & ND & No effect & Increased PSA & ND & ND & ND & $\begin{array}{l}\text { Zelivianski et al. } \\
\text { (2001) }\end{array}$ \\
\hline & LNCaP (C-81) & ND & ND & NSE & Decreased AR & ND & ND & ND & \\
\hline \multirow{2}{*}{$\begin{array}{c}\mathrm{db}-c A M P+ \\
\text { IBMX }\end{array}$} & LNCaP & Yes & ND & $\mathrm{CgA}$ & ND & ND & ND & ND & Bang et al. (1994) \\
\hline & PC-3M & Yes & Yes & NSE/CgA/S-100 & ND & ND & ND & ND & \\
\hline $\begin{array}{l}\text { db-cAMP }+ \\
\text { IBMX }\end{array}$ & LNCaP/C4-2 & Yes & Yes & NSE/Serotonin & ND & ND & ND & $\mathrm{R}$ & Cox et al. (1999) \\
\hline $\begin{array}{l}\text { Forskolin }+ \\
\text { IBMX }\end{array}$ & LNCaP & Yes & Yes & $\begin{array}{l}\text { NSE, secreted } \\
\text { PTHrP/NT }\end{array}$ & ND & ND & ND & $\mathrm{R}$ & \\
\hline \multirow[t]{2}{*}{ Epinephrine } & LNCaP & Yes & Yes & NSE & ND & ND & ND & $\mathrm{R}$ & \\
\hline & LNCaP & Yes & Yes & $\begin{array}{l}\text { NSE, secreted } \\
\text { PTHrP/NT }\end{array}$ & ND & ND & ND & ND & Deeble et al. (2001) \\
\hline $\begin{array}{l}\text { Epinephrine }+ \\
\text { IL-6 }\end{array}$ & LNCaP & Yes & Yes & $\begin{array}{l}\text { NSE/ } \beta \text { III tubulin, } \\
\text { secreted } \\
\text { PTHrP/NT }\end{array}$ & ND & ND & ND & & \\
\hline \multicolumn{10}{|l|}{ Cytokines } \\
\hline \multirow[t]{7}{*}{ IL-6 } & LNCaP & Yes & ND & NSE & ND & ND & ND & ND & Qin et al. (1998) \\
\hline & LNCaP & Yes & Yes & NSE & ND & ND & ND & ND & Mori et al. (1999) \\
\hline & LNCaP & Yes & Yes & NSE/CgA & ND & ND & ND & ND & $\begin{array}{l}\text { Spiotto \& Chung } \\
(2000 a, b)\end{array}$ \\
\hline & LNCaP & Yes & Yes & $\beta$ III tubulin & ND & ND & ND & ND & Deeble et al. (2001) \\
\hline & LNCaP (C-33) & Yes & ND & NSE/CgA/GS/NT & Decreased PSA & ND & ND & ND & $\begin{array}{l}\text { Zelivianski et al. } \\
\text { (2001) }\end{array}$ \\
\hline & LNCaP (C-81) & ND & ND & No effect & $\begin{array}{c}\text { Decreased } \\
\text { PSA/AR }\end{array}$ & ND & ND & ND & \\
\hline & LNCaP & Yes & Yes & NSE/ $\beta I I I$ tubulin & $\begin{array}{c}\text { Decreased } \\
\text { PSA/AR }\end{array}$ & $\begin{array}{l}\text { Decreased } \\
\text { invasiveness }\end{array}$ & $\begin{array}{r}\text { Inhibiting } \\
\text { growth }\end{array}$ & ND & Wang et al. (2004b) \\
\hline
\end{tabular}




\begin{tabular}{|c|c|c|c|c|c|c|c|c|c|}
\hline Induction & Cell types & $\begin{array}{l}\text { NE-like } \\
\text { morphology }\end{array}$ & $\begin{array}{l}\text { Growth } \\
\text { arrest }\end{array}$ & $\begin{array}{l}\text { Marker } \\
\text { expression }\end{array}$ & $\begin{array}{l}\text { PSA/AR } \\
\text { expression }\end{array}$ & $\begin{array}{l}\text { Biological } \\
\text { phenotypes }\end{array}$ & $\begin{array}{l}\text { Paracrine } \\
\text { (CM) effects }\end{array}$ & $\mathbf{R} / \mathbf{R}$ & References \\
\hline IL-1 $\beta / I L-6$ & LNCaP/DU145 & ND & ND & $\mathrm{CgA}$ & ND & ND & ND & ND & Diaz et al. (1998) \\
\hline IL-1 $\beta$ & LNCaP & Yes & Yes & $\mathrm{CgA} /$ Serotonin/K8 & Decreased PSA & ND & ND & IR & Chiao et al. (1999) \\
\hline \multicolumn{10}{|c|}{ Protein overexpression } \\
\hline $\operatorname{RPTP} \alpha$ & LNCaP (C-33) & Yes & ND & $\begin{array}{l}\text { NSE/CgA/CgB/N- } \\
\text { T/PTHrP }\end{array}$ & ND & ND & ND & ND & $\begin{array}{l}\text { Zhang et al. (2003) } \\
\text { and Yuan et al. } \\
\text { (2006) }\end{array}$ \\
\hline PTP1B & LNCaP & ND & No & NSE/CgA & ND & ND & ND & ND & Wu et al. (2006) \\
\hline PCDH-PC & LNCaP/PC-3 & ND & ND & NSE/CgA & ND & ND & ND & ND & Yang et al. (2005) \\
\hline$\beta$-Catenin & LNCaP & ND & ND & NSE/CgA & ND & ND & ND & ND & \\
\hline $\operatorname{MEK}(\mathrm{CA})$ & LNCaP (C-33) & Yes & ND & NSE & ND & ND & ND & ND & Zhang et al. (2003) \\
\hline PKA (CA) & LNCaP & Yes & Yes & NSE & ND & ND & ND & ND & Cox et al. (2000) \\
\hline Stat3 (CA) & PC-3 & Yes & Yes & NSE & ND & ND & ND & ND & $\begin{array}{l}\text { Spiotto \& Chung } \\
(2000 b)\end{array}$ \\
\hline \multicolumn{10}{|c|}{ Pharmacological agents } \\
\hline Silibinin & LNCaP & Yes & Yes & $\mathrm{CgA} / \mathrm{K} 8 / \mathrm{K} 18$ & Decreased PSA & ND & ND & ND & Zi \& Agarwal (1999) \\
\hline $\begin{array}{l}\text { Sodium buty- } \\
\text { rate }\end{array}$ & LNCaP (C-33) & Yes & Yes & NSE & ND & ND & ND & ND & $\begin{array}{l}\text { Zelivianski et al. } \\
\text { (2001) }\end{array}$ \\
\hline JolkinolideB & LNCaP & Yes & Yes & NSE/K8/K18 & ND & ND & ND & ND & Liu et al. (2002) \\
\hline Genistein & LNCaP & Yes & ND & $\begin{array}{l}\beta I I I \text { tubulin/CgA/sy- } \\
\text { naptophysin/ser- } \\
\text { otonin }\end{array}$ & ND & ND & $\begin{array}{l}\text { Inhibiting colony } \\
\text { formation }\end{array}$ & ND & Pinski et al. (2006) \\
\hline \multicolumn{10}{|c|}{ Growth factors/neuropeptides } \\
\hline HB-EGF & LNCaP & Yes & No & NSE & ND & ND & ND & ND & Kim et al. (2002) \\
\hline EGF & DU145 & Yes & Yes & NSE & ND & ND & ND & ND & Humez et al. (2006) \\
\hline VIP & LNCaP & Yes & ND & NSE & ND & ND & ND & ND & $\begin{array}{l}\text { Gutierrez-Canas et } \\
\text { al. (2005) }\end{array}$ \\
\hline PACAP & LNCaP & Yes & Yes & NT & ND & ND & ND & ND & Farini et al. (2003) \\
\hline
\end{tabular}

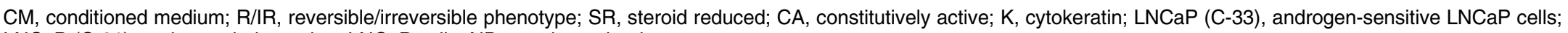
LNCaP (C-81), androgen-independent LNCaP cells; ND, not determined. 


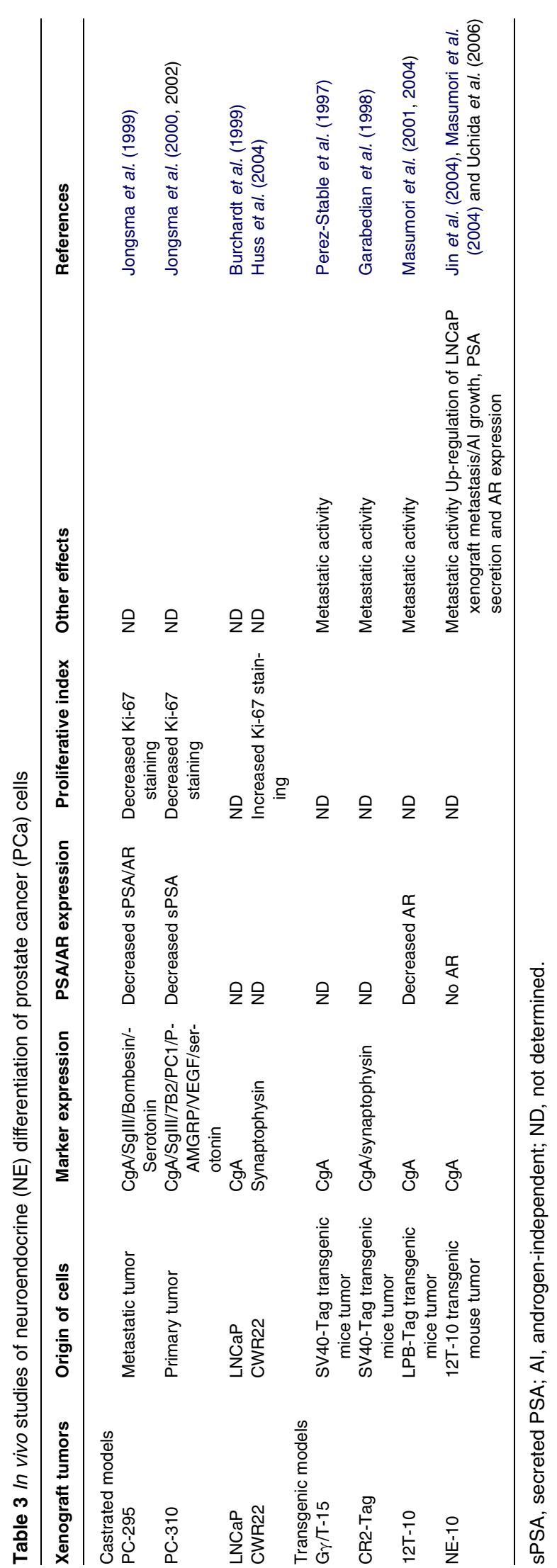

resulting in NE transdifferentiation of $\mathrm{PCa}$ cells (Fig. 2).

\section{PTP1B-mediated signal pathway}

The expression of PTP1B, a cytosolic PTP, is also found to have an elevated level in NE-differentiated LNCaP cells induced by androgen depletion (Wu et al. 2006). In the regular culture condition containing androgenic activity, increased expression of PTP1B in LNCaP cells can lead to NE differentiation. In an androgen-deprived condition, increased PTP1B expression or activity in LNCaP cells synergistically enhances NE marker expression. Conversely, the expression of a dominant-negative mutant of PTP1B blocks the upregulation of $\mathrm{CgA}$ expression in response to androgen withdrawal (Wu et al. 2006). Thus, PTP1B may play a role in androgen depletion-induced $\mathrm{NE}$ differentiation. Consistently, immunostaining of $\mathrm{PCa}$ archival specimens revealed the co-expression of PTP1B and CgA in tissues examined (Wu et al. 2006). Although the underlying mechanism of PTP1Binduced NE differentiation of PCa cells requires further investigation, PTP1B may activate the transdifferentiation process through upregulating the Ras-ERK/ MAPK signaling (Dube et al. 2004). Alternatively, PTP1B, similar to RPTP $\alpha$, can directly activate c-Src as observed in breast cancer cells (Bjorge et al. 2000). PTP1B-induced NE differentiation may also be mediated by AKT activation (Wu \& Huang 2007).

\section{Protocadherin-PC (PCDH-PC)-mediated signal pathway}

PCDH-PC, a member of the protocadherin gene family encoded on the human $\mathrm{Y}$ chromosome, is selectively expressed in hormone-resistant $\mathrm{PCa}$ cells (Chen et al. 2002, Terry et al. 2006). The expression of PCDH-PC is upregulated in androgen-depleted LNCaP cells and in LNCaP xenograft tumors from castrated male mice (Chen et al. 2002). Increased expression of PCDH-PC leads to the activation of Wnt signaling, including the nuclear translocation of $\beta$-catenin and increased Tcf transcriptional activity (Yang et al. 2005). Elevated expression of $\mathrm{PCDH}-\mathrm{PC}$ by cDNA transfection in $\mathrm{LNCaP}$ and PC-3 cells upregulates NSE and $\mathrm{CgA}$ expression, while its decreased expression by siRNA oligomers in LNCaP cells abolishes androgen depletion or PCDH-PC-induced NSE expression. Furthermore, NE transdifferentiation of LNCaP cells could be induced by $\beta$-catenin cDNA transfection or blocked by its siRNA oligomers (Yang et al. 


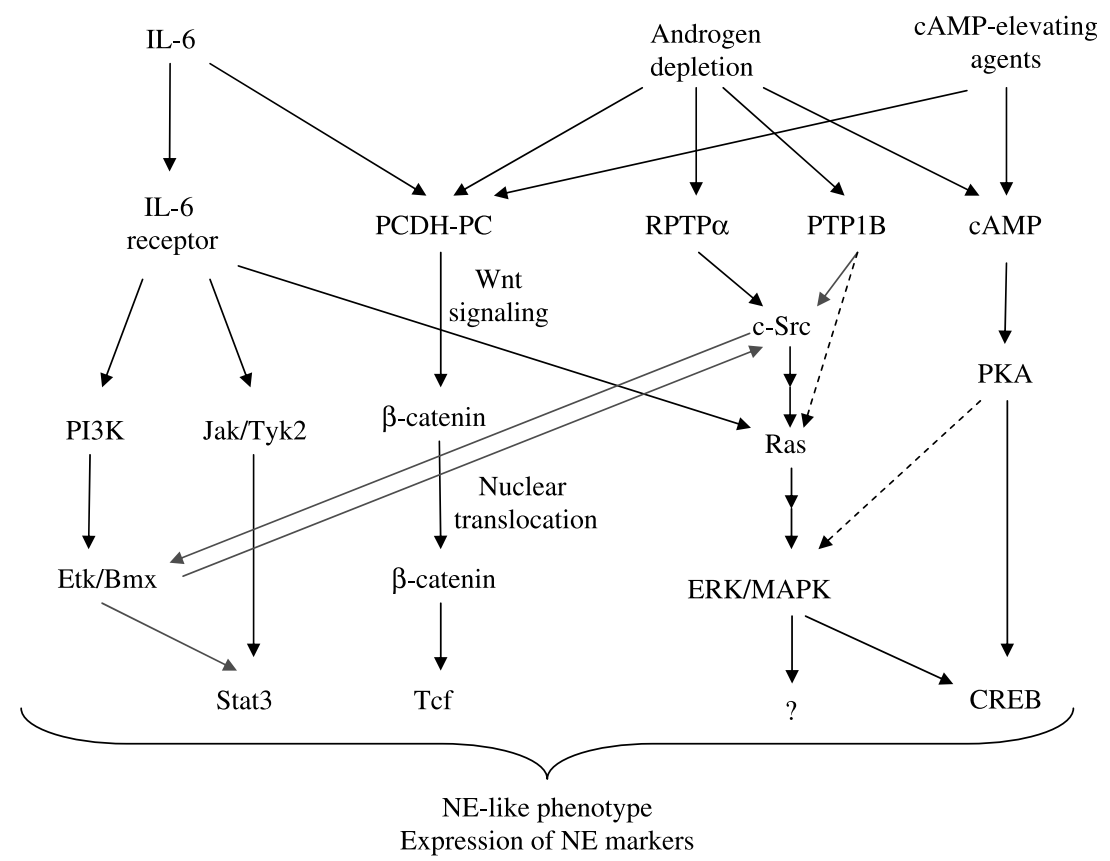

Figure 2 Signal transduction pathways associated with the induction of NE transdifferentiation of PCa cells. The solid line indicates the reported pathways, while the dash line indicates the hypothetical pathways.

2005). These data together suggest that increased PCDH-PC expression in response to androgen deprivation via Wnt signaling plays a role in $\mathrm{NE}$ differentiation of $\mathrm{PCa}$ cells.

\section{cAMP and its agonists-induced NE differentiation}

Several lines of evidence show that elevation of intracellular cAMP leads to NE differentiation of AS and AI PCa cells (Table 2). Bang et al. (1994) first showed that increased cAMP, by adding cAMP analogs and phosphodiesterase inhibitors to AS LNCaP or AI PC-3M cell culture medium, induces their NE differentiation by acquiring neuron-like morphology, expressing NE markers, and suppressing cell growth. Further studies showed that elevation of intracellular cAMP by forskolin, an activator of adenylate cyclase, or epinephrine, a $\beta$-adrenergic receptor agonist, induces NE transdifferentiation of LNCaP cells (Cox et al. 1999). Additionally, androgen depletion also leads to cAMP elevation in AS LNCaP cells, correlated with NE differentiation (Burchardt et al. 1999). Nevertheless, the NE characteristics induced by cAMP-elevating agents are fully reversible upon the removal of the stimuli (Cox et al. 1999).

\section{Mechanisms of cAMP-induced NE differentiation}

Since increased cAMP induces the activation of protein kinase A (PKA) and treatment of epinephrine also leads to PKA activation (Deeble et al. 2001), it is thus proposed that PKA is mediating cAMP-induced transdifferentiation of $\mathrm{PCa}$ cells. This notion is supported by the observation that overexpression of PKA catalytic subunit in LNCaP cells leads to $\mathrm{NE}$ differentiation, while expression of a dominantnegative mutant of PKA blocks NE differentiation induced by cAMP-elevating agents (Cox et al. 2000). Since ERK/MAPK signal pathway crosstalks with cAMP/PKA-regulated proliferation and differentiation in several cell types (Stork \& Schmitt 2002), ERK/ MAPK may also play a role in the cAMP-elevating agent-induced NE differentiation of PCa cells. For example, epinephrine and db-cAMP treatments in LNCaP cells lead to ERK/MAPK activation (Chen et al. 1999). However, in other studies, the withdrawal of db-cAMP/IBMX from NE-differentiated LNCaP cells results in ERK/MAPK activation (Cox et al. 1999). Additionally, epinephrine treatment has no significant effect on ERK/MAPK activity in LNCaP cells, although it can lead to an increased cAMP level, the PKA activation, and the induction of NE differentiation (Deeble et al. 2001). The inconsistent observations could be contributed by different experimental conditions. It has been shown that transient cAMP accumulation in LNCaP cells leads to proliferation through PKA-dependent ERK/MAPK activation, while sustained elevation of cAMP level increases 
PKA activity resulting in NE differentiation by a PKAdependent but ERK/MAPK-independent mechanism (Farini et al. 2003). The role of ERK/MAPK in cAMP/ PKA signaling-mediated NE differentiation in PCa cells requires further investigation.

\section{Cytokines-induced NE differentiation}

Cytokines, a diverse group of secreted peptides, function as signaling molecules to mediate immune and inflammatory responses as well as to regulate the proliferation and maturation of immune cells. Importantly, cytokines such as interleukins can also regulate the proliferation and differentiation of non-immune cells, including PCa cells. Results of clinical studies reveal that the serum level of interleukin-6 (IL-6) is elevated in patients with $\mathrm{PCa}$, especially hormonerefractory and metastatic PCa (Adler et al. 1999, Drachenberg et al. 1999, Shariat et al. 2001). Furthermore, the levels of IL-6 and its receptor in $\mathrm{PCa}$ tissues are significantly higher than that in normal prostate tissues (Siegsmund et al. 1994, Giri et al. 2001). These results clearly show the correlation of IL-6 expression with PCa progression and thus suggest that IL-6 may serve as a marker for PCa morbidity (Twillie et al. 1995). Since elevated IL-6 level is associated with advanced PCa and correlated with increased NE differentiation, it is proposed that IL-6 is one of the important inducers of NE differentiation of $\mathrm{PCa}$ cells. Indeed, IL-6 treatment induces NE transdifferentiation of LNCaP cells (Qiu et al. 1998), indicated by neuron-like morphology, reduced cell growth, and elevated NE marker expression (Table 2). Furthermore, in the absence of ligand, elevated expression of constitutively active gp130, the signal transduction subunit of IL-6 receptor, in LNCaP cells induces NE transdifferentiation in cell cultures and in animal model studies, indicating IL-6-induced NE differentiation of PCa cells (Palmer et al. 2005). Additionally, IL-1 $\beta$, a pro-inflammatory cytokine, can also induce NE differentiation of PCa cells (Diaz et al. 1998, Chiao et al. 1999). These results collectively suggest a role of cytokines in the NE differentiation of PCa cells.

\section{Mechanisms of IL-6-induced NE differentiation}

IL-6-induced NE differentiation may be mediated by Stat3 transcription factor. Initial studies showed that the transcriptional activity of Stat 3 is required for IL-6induced growth arrest in LNCaP cells (Spiotto \& Chung 2000a), in addition to the involvement of other pathways (Mori et al. 1999). Since growth arrest and differentiation are associated processes, Stat 3 may also mediate IL-6-induced NE differentiation in PCa cells. Consistently, stable expression of the wild-type Stat3 in PC-3 cells results in the formation of neurite extensions, elevated NSE expression, and growth arrest (Spiotto \& Chung 2000b). Furthermore, LNCaP cells stably expressing a dominant-negative mutant of Stat 3 fail to undergo NE transdifferentiation process in the presence of IL-6, suggesting the critical role of Stat3 in IL-6-induced NE differentiation (Spiotto \& Chung 2000b). Interestingly, IL-6-mediated Stat3 phosphorylation, nuclear translocation, and NE differentiation are closely associated with cholesterolrich membrane lipid rafts. In $\mathrm{LNCaP}$ cells, the disruption of lipid rafts inhibits IL-6-mediated effects, probably because IL-6 receptors predominantly localizes to the lipid raft membrane compartment (Kim et al. 2004). Additionally, tyrosine kinase Etk/Bmx has been shown to play an important role in IL-6-induced NE differentiation (Qiu et al. 1998). Etk/Bmx may activate c-Src, Stat3, and/or PI3K for NE differentiation (Spiotto \& Chung 2000b, Tsai et al. 2000, Chau et al. 2005). Alternatively, c-Src can activate the Etk/ Bmx-Stat3 pathway (Tsai et al. 2000). Further investigation is apparently needed.

\section{Clinical relevance of IL-6-induced NE differentiation}

IL-6-induced NE differentiation has been clearly demonstrated in LNCaP cells in culture; however, the role of those IL-6-induced NE-like cells in clinical prostate tumor progression is less understood. Studies showed that IL-6 inhibits the growth of LNCaP xenografts, despite the fact that those tumors exhibit NE characteristics including elevated levels of NSE and $\beta$-III tubulin (Wang et al. 2004a). Furthermore, co-culture of IL-6-induced NE-like cells with LNCaP, PC-3, or DU145 cells leads to cell cycle arrest and DNA synthesis inhibition (Wang et al. 2004b). These results suggest that IL-6-induced NE differentiation leads to the growth inhibition of surrounding PCa cells, probably via the release of inhibitory factors by IL-6induced NE-like cells (Wang et al. 2004b). While the underlying mechanism still requires further investigations, these results are opposite to the observations in clinical specimens that the NE cell-proximal PCa cells exhibit higher proliferation indices than the distal $\mathrm{PCa}$ cells (Bonkhoff et al. 1995). The data suggest that clinical NE cells in PCa lesions secrete growth stimulatory factors to enhance proximal $\mathrm{PCa}$ cell proliferation. It should also be noted that IL-6 exhibits a growth stimulatory effect on the primary prostate epithelial cells as well as a cell line derived from a 
precancerous lesion and high-grade prostatic intraepithelial neoplasia (Giri et al. 2001, Liu et al. 2002b). The contradictory effects of IL-6 on both PCa cell proliferation and $\mathrm{NE}$ differentiation may result from the bifunctional character of IL-6. It has been proposed that the paracrine effect by IL-6 leads to the growth inhibition and NE differentiation, while the autocrine effect by IL- 6 causes the growth stimulation (Lee et al. 2007). Evidently, the role of IL-6-induced NE differentiation of PCa cells in clinical PCa progression under AI condition requires further clarification.

\section{Other factors in NE differentiation}

Results from studies clearly suggest multiple pathways for inducing NE transdifferentiation of $\mathrm{PCa}$ cells (Table 2 and Fig. 2; Zelivianski et al. 2001). For example, HB-EGF, an EGFR ligand serving as a mitogenic and survival factor for PCa cells, can also promote $\mathrm{NE}$ differentiation in vitro and in vivo (Adam et al. 2002, Kim et al. 2002). HB-EGF activates EGFR via ERK/MAPK to induce NE differentiation of LNCaP cells (Kim et al. 2002). Similarly, activation of EGFR by EGF can also induce NE differentiation of DU145 cells although the underlying molecular basis remains unclear (Humez et al. 2006). Contrarily, treatment of genistein, a classical tyrosine kinase inhibitor, has been shown to be associated with NE differentiation of LNCaP cells, which is correlated with the activation of Stat3 and ERK/MAPK (Pinski et al. 2006). Additionally, treatment of genistein abolishes EGF-induced NE differentiation of DU145 cells (Humez et al. 2006), and conditioned media from genistein-induced NE-like LNCaP cells have an inhibitory effect on the growth of PC-3 and DU145 cells (Pinski et al. 2006). Vasoactive intestinal peptide (VIP) is a neuropeptide and can also promote NE differentiation of LNCaP cells (Juarranz et al. 2001). Further studies reveal that VIP-induced NE differentiation is mediated by the activation of multiple signaling molecules, including PKA, ERK/MAPK, and PI3K (Gutierrez-Canas et al. 2005). Interestingly, intracellular calcium level is also associated with the development of NE phenotype in PCa cells (Vanoverberghe et al. 2004). Calcium chelator BAPTA/AM inhibits VIP-induced NE phenotype in LNCaP cells (Collado et al. 2005), while increased expression of calcium channel proteins in $\mathrm{LNCaP}$ cells promotes $\mathrm{NE}$ differentiation (Mariot et al. 2002). The treatments of some anticancer agents, such as jolkinolide B and silibinin, are also reported to be correlated with the induction of NE differentiation in LNCaP cells ( $\mathrm{Zi} \&$ Agarwal 1999, Liu et al. 2002a). The data collectively support the notion that NE differentiation of PCa cells is mediated by multiple signal pathways, in part due to the heterogeneity of PCa cells (Zelivianski et al. 2001), and $\mathrm{PCa}$ cells can indeed transdifferentiate into NE-like cells.

\section{Summary}

Although several studies have shown interesting results regarding the $\mathrm{NE}$ transdifferentiation of $\mathrm{PCa}$ cells in cultures as well as in animal models, it remains for further investigations to determine whether those transdifferentiated NE-like cells exhibit the similar biochemical properties as that of clinical NE-like PCa cells. For example, the biochemical information of those transdifferentiated NE-like cells, such as the expression profiles of NE markers, the paracrine effect and the tumorigenic activity, is limited. It is because most of transdifferentiation processes induced by various reagents are transient and cells can fully revert to their original phenotype in the absence of inducers. As such, they are apparently different from those terminally differentiated clinical NE-like PCa cells; nor can they be used for studying the interaction between NE-like PCa and prostatic carcinoma cells. To elucidate the molecular basis of NE differentiation and their roles in PCa progression, stable NE-like PCa cell lines of clinical relevance are imperatively needed.

\section{An NE-like PCa cell model Establishment and characterization of NE-like LNCaP subclone cells}

To investigate the molecular mechanism of $\mathrm{NE}$ differentiation and its role in $\mathrm{PCa}$, we established NE-like PCa cell lines by culturing AS LNCaP cells in an androgen-depleted condition, resembling clinical androgen ablation therapy. By prolonged culturing in an androgen-reduced medium, AS LNCaP cells transdifferentiate into NE-like cells and several subclone cells grew to become independent cell lines. These NE-like LNCaP subclone cells exhibit a neuronal morphology, differing from AS LNCaP parental cells (Zhang et al. 2003, Yuan et al. 2006). Importantly, these NE-like LNCaP subclone cells share the same genetic profile with AS LNCaP parental cells (Yuan et al. 2006), corresponding to the observation that NE-like PCa cells in tumor lesions have essentially identical genetic profiles with adjacent exocrine $\mathrm{PCa}$ cells (Sauer et al. 2006).

Expression of neuron-specific markers and neuropeptides is one of the major hallmarks of NE-like PCa cells in tumor lesions. Studies in three NE-like LNCaP 
Table 4 Prostatic neuroendocrine (NE) xenografts and cell models

\begin{tabular}{|c|c|c|c|c|c|c|c|}
\hline Name & Origin of cells & $\begin{array}{l}\text { NE-like } \\
\text { morphology }\end{array}$ & Marker expression & $\begin{array}{l}\text { PSA/AR } \\
\text { expression }\end{array}$ & $\begin{array}{l}\text { Biological } \\
\text { phenotypes }\end{array}$ & $\begin{array}{l}\text { Paracrine }(\mathrm{CM}) \\
\text { effects }\end{array}$ & References \\
\hline \multicolumn{8}{|l|}{ Xenograft models } \\
\hline UCRU-Pr-2 & $\begin{array}{l}\text { Primary NE tumor } \\
\text { (human) }\end{array}$ & ND & $\begin{array}{l}\text { NSE/somatostatin } \beta \text {-endor- } \\
\text { phin/ATCH }\end{array}$ & No PSA/AR & ND & ND & $\begin{array}{l}\text { van Haaften-Day et al. } \\
\text { (1987) and Jelbart et al. } \\
\text { (1988) }\end{array}$ \\
\hline WISH-PC2 & $\begin{array}{l}\text { Primary tumor } \\
\text { (human) }\end{array}$ & ND & $\begin{array}{l}\text { NSE/CgA/synaptophysin/- } \\
\text { K8/K18/Bcl-2 }\end{array}$ & $\begin{array}{l}\text { No sPSA/ } \\
\text { PSA/AR }\end{array}$ & $\begin{array}{l}\text { Metastatic activity } \\
\text { High Ki-67 staining }\end{array}$ & ND & Pinthus et al. (2000) \\
\hline LuCaP 49 & $\begin{array}{l}\text { Metastatic tumor } \\
\quad \text { (human) }\end{array}$ & ND & NSE/synaptophysin/VEGF & No sPSA/AR & $\begin{array}{l}75 \% \text { of cells with } \mathrm{Ki}-67 \\
\text { staining }\end{array}$ & ND & True et al. (2002) \\
\hline \multicolumn{8}{|l|}{ SCC cell lines } \\
\hline $\mathrm{NCl}-\mathrm{H} 660$ & $\begin{array}{l}\text { Metastatic NE } \\
\text { tumor (human) }\end{array}$ & ND & NSE/CgA/CgB/K8/K18 & No PSA/AR & Metastatic activity & ND & $\begin{array}{l}\text { Johnson et al. (1989) and } \\
\text { van Bokhoven et al. } \\
\text { (2003) }\end{array}$ \\
\hline PSK-1 & $\begin{array}{l}\text { Primary NE tumor } \\
\text { (human) }\end{array}$ & No & NSE/CgA/K8/K18 & No PSA/AR & Tumorigenic activity & ND & $\begin{array}{r}\text { Kim et al. (2000) and van } \\
\text { Bokhoven et al. (2003) }\end{array}$ \\
\hline SO-MI & $\begin{array}{l}\text { Primary NE tumor } \\
\text { (human) }\end{array}$ & Yes & NSE/CgA & No PSA/AR & ND & ND & Okada et al. (2003) \\
\hline NE-CS & $\begin{array}{l}\text { NE-10 allograft } \\
\text { (mouse) }\end{array}$ & Yes & Secreted serotonin & No AR & $\begin{array}{l}\text { Tumor development in } \\
\text { nude mice }\end{array}$ & $\begin{array}{l}\text { Up-regulation of } \\
\text { cell migration } \\
\text { and invasion }\end{array}$ & Uchida et al. $(2005,2006)$ \\
\hline \multicolumn{8}{|c|}{ Trans differentiated NE cell line } \\
\hline $\begin{array}{l}\text { NE-like LNCaP sub- } \\
\text { clone cells }\end{array}$ & $\begin{array}{l}\text { Androgen } \\
\text { depleted-LNCaP } \\
\text { (C-33) cells }\end{array}$ & Yes & $\begin{array}{l}\text { NSE/CgA/CgB/NT/PTHrP/- } \\
\text { K8/K18 }\end{array}$ & No PSA/AR & $\begin{array}{l}\text { Tumor development in } \\
\text { nude mice }\end{array}$ & $\begin{array}{l}\text { Up-regulation of } \mathrm{Al} \\
\text { growth, PSA } \\
\text { secretion }\end{array}$ & Yuan et al. (2006) \\
\hline
\end{tabular}

CM, conditioned medium; SCC, small cell carcinoma; sPSA, secreted PSA; Al, androgen-independent; LNCaP (C-33), androgen-sensitive LNCaP cells; ND, not determined. 
subclone cells have revealed that they differentially express elevated levels of multiple NE markers and neuropeptides, including $\mathrm{NSE}, \mathrm{CgA}, \mathrm{CgB}$, NT, and PTHrP, compared with LNCaP parental cells (Yuan et al. 2006; Table 4). Furthermore, these NE-like LNCaP subclone cells express $\mathrm{K} 8$ and $\mathrm{K} 18$, two prominent markers for luminal epithelial cells, higher than LNCaP parental cells (Yuan et al. 2006). Similarly, in clinical archival specimens, over $90 \%$ of serotonin-positive prostatic NE cells and two cell lines derived from prostatic small cell carcinomas express K18 (Xue et al. 1997, van Bokhoven et al. 2003; Table 4). This observation is in parallel with the expression of PAcP, a prostate secretory epitheliumspecific differentiation antigen, in these NE-like LNCaP subclone cells and clinical NE-like PCa cells in prostate carcinomas (Abrahamsson 1999, Yuan et al. 2006). Importantly, these NE-like LNCaP subclone cells do not express AR and PSA (Yuan et al. 2006), similar to those NE-like PCa cells found in the archival specimens (Bonkhoff 2001, Huang et al. 2006). Additionally, these NE-like LNCaP subclone cells express an elevated level of Bcl-2 (Yuan et al. 2006), correlated with the observation in clinical small cell carcinoma cells (Yao et al. 2006). Significantly, even after a 3-month re-culturing in a medium containing androgenic activity, these NE-like LNCaP subclone cells retain the NE phenotype and express NE markers, indicating a terminal transdifferentiation. Collectively, our NE-like LNCaP subclone cells resemble those NE-like PCa cells in clinical samples and are suitable for further biochemical characterizations.

The functional characterizations further reveal the clinical relevance of these NE-like subclone cells. Results of studies in prostatic small cell carcinomas indicate that those clinical NE-like PCa cells are highly aggressive and exhibit a malignant phenotype (Abrahamsson 1999). Corresponding to the clinical observations, our NE-like LNCaP subclone cells exhibit high tumorigenicity. These NE-like subclone cells have a greater tumorigenic activity in xenograft animals and a higher clonogenic activity, but a lower proliferation rate in culture, than AS LNCaP parental cells (Yuan et al. 2006). Importantly, conditioned media $(\mathrm{CM})$ by these NE-like subclone cells, but not by LNCaP parental cells, can stimulate the growth and PSA secretion from LNCaP cells under an androgen-reduced condition (Yuan et al. 2006), corresponding to the observation that clinical NE-like $\mathrm{PCa}$ cells have a mitogenic effect on adjacent cancer cells. Thus, the data collectively suggest that these NE-like LNCaP subclone cells, similar to NE-like PCa cells observed in clinical studies, exhibit a

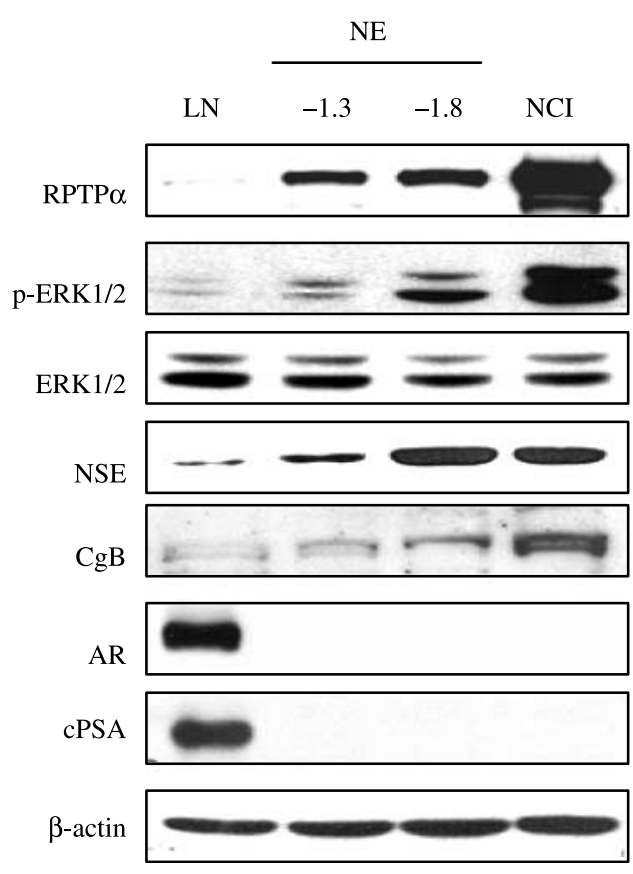

Figure 3 Biochemical characterizations of NE-like LNCaP stable subclone and small cell carcinoma cells. Androgen-sensitive LNCaP parental cells (LN) were plated and maintained in the regular medium, while two NE-like LNCaP subclone cells, i.e., NE1.3, NE-1.8, and small cell carcinoma $\mathrm{NCl}-\mathrm{H} 660(\mathrm{NCl})$ cells were grown in a steroid-reduced medium. An aliquot of total cell lysates was separated by SDS-PAGE and transferred to nitrocellulose membranes for immunoblotting with Abs against RPTP $\alpha$, phospho-ERK1/2, ERK1/2, NSE, CgB, AR, and cellular PSA (CPSA) respectively. As an internal loading control, the level of $\beta$-actin on the same membrane was examined.

malignant phenotype and have a paracrine effect on AI proliferation of PCa cells.

\section{RPTP $\propto$ signaling in NE-like LNCaP subclone cells}

As described earlier that RPTP $\alpha$ plays a role in androgen depletion-induced NE differentiation, RPTP $\alpha$ is highly expressed in these NE-like LNCaP subclone cells and its expression level is associated with increased ERK/MAPK activity as well as elevated NSE expression, compared with LNCaP parental cells (Fig. 3; Zhang et al. 2003, Yuan et al. 2006). We further compared our NE-like LNCaP subclone cells with NCI-H660 cells, a prostatic small cell carcinoma cell line (Johnson et al. 1989). As shown in Fig. 3, NCI-H660 cells express a high level of RPTP $\alpha$, even higher than both NE-1.3 and NE-1.8 cells, correlated with activation of ERK/MAPK by phosphorylation. As a control, LNCaP parental cells express a low level of RPTP $\alpha$ and exhibit very low ERK/MAPK activity. Furthermore, NCI-H660 cells, similar to NE-1.3 and NE-1.8 cells, expressed elevated levels of NE markers but no AR and PSA expression (Fig. 3). 
These results further support the functional importance of RPTP $\alpha$ in NE differentiation of PCa cells.

\section{Conclusions and prospectives}

Accumulated evidence has suggested the roles of NE-like PCa cells in PCa progression and has also revealed that their biological characteristics are different from the normal NE cells. Furthermore, NE-like $\mathrm{PCa}$ cells are originated from cancerous luminal epithelial cells, but not from normal NE cells, via a transdifferentiation process. This notion is supported by the fact that those NE-like cells in $\mathrm{PCa}$ lesions exhibit the same genetic profile as PCa cells in cancerous lesions but not NE cells in normal tissues both from the same specimen (Sauer et al. 2006). We propose that those NE-like cells in PCa lesions should be defined as 'NE-like PCa cells' to accurately reflect their origin. While several factors may induce NE transdifferentiation via multiple signal pathways, the constitutive ERK/MAPK activation apparently plays a critical role in converging multiple signalings for $\mathrm{NE}$ differentiation in PCa cells (Fig. 2). Thus, we propose that activation of ERK/MAPK is one of the major mechanisms in the transdifferentiation of PCa cells into NE-like cells. We further propose that sustained, but not transient, hyperactivation of ERK/MAPK is required to support the NE transdifferentiation process of PCa cells, similar to NE differentiation of PC-12 cells (Marshall 1995). This notion is supported by the observations in NCI-H660 and our NE-like stable subclone cells that exhibit a high and sustained level of ERK/MAPK activity (Fig. 3). In parallel, constitutive activation of ERK/MAPK is observed in PCa archival specimens, including advanced hormone-refractory tumors (Gioeli et al. 1999, Price et al. 1999). Therefore, ERK/MAPK activation plays an important role in NE transdifferentiation of PCa cells and may serve as a target for developing new therapeutic approaches for PCa therapy.

It should also be pointed out that $\mathrm{NE}$ tumors are rare for $\mathrm{PCa}$, and the post-mitotic NE-like PCa cells in tumor lesions may be one or two steps away from becoming NE tumors. The transition from the postmitotic NE-like PCa cells to highly aggressive NE tumor cells, such as small cell carcinoma cells, may occur after additional genetic alterations. In parallel, the NE-like LNCaP subclone cells were established after growth silence in SR condition. Interestingly, studies from the TRAMP mouse model as well as the $\mathrm{Rb} / \mathrm{p53}$-null mice showed that the simultaneous inactivation or knockout of both p53 and $\mathrm{Rb}$ genes promotes NE differentiation of PCa (Perez-Stable et al.
1997, Zhou et al. 2006). While LNCaP cells express the wild-type p53 (Isaacs et al. 1991, Carroll et al. 1993), NCI-H660, and PSK-1, two human prostatic small cell carcinoma cell lines, exhibit truncated and mutated p53 proteins respectively (van Bokhoven et al. 2003). Despite that further investigation on the molecular characterization of those NE-like LNCaP subclone cells is required; it is possible that those NE-like LNCaP subclone cells have acquired additional genetic alterations, such as p53 or $\mathrm{Rb}$ mutation/deletion seen in a subpopulation of advanced $\mathrm{PCa}$, which cause the transition from the post-mitotic NE-like PCa cells to highly aggressive NE tumor cells. Thus, our NE-like LNCaP subclone cells provide a useful model to study both NE-like $\mathrm{PCa}$ and NE tumor cells.

It is an urgent need to have proper cell lines for studying the biological significance of NE-like PCa cells. Our NE-like LNCaP stable subclone cells acquires many features of clinical NE-like PCa cells, including irreversible NE phenotype, the same genetic profile as the parental PCa cells, expression of multiple NE markers, lack of AR or PSA expression, and high tumorigenicity in xenograft animals. Importantly, the paracrine effect of these NE-like subclone cells on AI proliferation as well as PSA secretion by $\mathrm{LNCaP}$ parental cells in SR conditions is in parallel with clinical observations that the proliferation index of cancer cells adjacent to NE-like PCa cells is increased and the circulation level of PSA in a hormonerefractory PCa patient is rebound. In summary, these NE-like LNCaP stable subclone cells can serve as a useful cell model to further explore the molecular mechanism of NE differentiation and its role in PCa for developing targeted therapy.

\section{Acknowledgements}

We thank Ms Fen-Fen Lin for the tremendous effort of establishing NE-like LNCaP stable subclone cell lines. We also thank Dr P Anthony di Sant'Agnese at the Department of Pathology, University of Rochester Medical Center for the constructive discussion and suggestions in the concept of 'NE-like PCa cells'. This study was supported in part by NIH grants CA88184, P20RR018759, DOD Army PCa program PC050769, Nebraska Research Initiative, UNMC College of Medicine Dean's Research Grant Award and Graduate Student Fellowship. The authors declare that there is no conflict of interest that would prejudice the impartiality of this scientific work. 


\section{References}

Abrahamsson PA 1999 Neuroendocrine cells in tumour growth of the prostate. Endocrine-Related Cancer $\mathbf{6}$ 503-519.

Adam RM, Kim J, Lin J, Orsola A, Zhuang L, Rice DC \& Freeman MR 2002 Heparin-binding epidermal growth factor-like growth factor stimulates androgen-independent prostate tumor growth and antagonizes androgen receptor function. Endocrinology 143 4599-4608.

Adler HL, McCurdy MA, Kattan MW, Timme TL, Scardino PT \& Thompson TC 1999 Elevated levels of circulating interleukin- 6 and transforming growth factor- $\beta 1$ in patients with metastatic prostatic carcinoma. Journal of Urology 161 182-187.

Aumuller G, Leonhardt M, Janssen M, Konrad L, Bjartell A \& Abrahamsson PA 1999 Neurogenic origin of human prostate endocrine cells. Urology 53 1041-1048.

Bang YJ, Pirnia F, Fang WG, Kang WK, Sartor O, Whitesell L, Ha MJ, Tsokos M, Sheahan MD, Nguyen P et al. 1994 Terminal neuroendocrine differentiation of human prostate carcinoma cells in response to increased intracellular cyclic AMP. PNAS 91 5330-5334.

Bjorge JD, Pang A \& Fujita DJ 2000 Identification of proteintyrosine phosphatase $1 \mathrm{~B}$ as the major tyrosine phosphatase activity capable of dephosphorylating and activating c-Src in several human breast cancer cell lines. Journal of Biological Chemistry 275 41439-41446.

van Bokhoven A, Varella-Garcia M, Korch C, Johannes WU, Smith EE, Miller HL, Nordeen SK, Miller GJ \& Lucia MS 2003 Molecular characterization of human prostate carcinoma cell lines. Prostate 57 205-225.

Bonkhoff H 1998 Neuroendocrine cells in benign and malignant prostate tissue: morphogenesis, proliferation, and androgen receptor status. Prostate. Supplement 8 18-22.

Bonkhoff H 2001 Neuroendocrine differentiation in human prostate cancer. Morphogenesis, proliferation and androgen receptor status. Annals of Oncology 12 141-144.

Bonkhoff H, Stein U \& Remberger K 1995 Endocrineparacrine cell types in the prostate and prostatic adenocarcinoma are postmitotic cells. Human Pathology 26 167-170.

Burchardt T, Burchardt M, Chen MW, Cao Y, de la Taille A, Shabsigh A, Hayek O, Dorai T \& Buttyan R 1999 Transdifferentiation of prostate cancer cells to a neuroendocrine cell phenotype in vitro and in vivo. Journal of Urology 162 1800-1805.

Chau CH, Clavijo CA, Deng HT, Zhang Q, Kim KJ, Qiu Y, Le AD \& Ann DK 2005 Etk/Bmx mediates expression of stress-induced adaptive genes VEGF, PAI-1, and iNOS via multiple signaling cascades in different cell systems. American Journal of Physiology. Cell Physiology 289 444-454.

Chen T, Cho RW, Stork PJ \& Weber MJ 1999 Elevation of cyclic adenosine $3^{\prime}, 5^{\prime}$-monophosphate potentiates activation of mitogen-activated protein kinase by growth factors in LNCaP prostate cancer cells. Cancer Research 59 213-218.
Chen MW, Vacherot F, De La Taille A, Gil-Diez-De-Medina S, Shen R, Friedman RA, Burchardt M, Chopin DK \& Buttyan R 2002 The emergence of protocadherin-PC expression during the acquisition of apoptosis-resistance by prostate cancer cells. Oncogene 21 7861-7871.

Cheville JC, Tindall D, Boelter C, Jenkins R, Lohse CM, Pankratz VS, Sebo TJ, Davis B \& Blute ML 2002 Metastatic prostate carcinoma to bone: clinical and pathologic features associated with cancer-specific survival. Cancer 95 1028-1036.

Chiao JW, Hsieh TC, Xu W, Sklarew RJ \& Kancherla R 1999 Development of human prostate cancer cells to neuroendocrine-like cells by interleukin-1. International Journal of Oncology 15 1033-1037.

Collado B, Sanchez MG, Diaz-Laviada I, Prieto JC \& Carmena MJ 2005 Vasoactive intestinal peptide (VIP) induces c-fos expression in LNCaP prostate cancer cells through a mechanism that involves $\mathrm{Ca} 2+$ signalling. Implications in angiogenesis and neuroendocrine differentiation. Biochimica et Biophysica Acta 1744 224-233.

Cox ME, Deeble PD, Lakhani S \& Parsons SJ 1999

Acquisition of neuroendocrine characteristics by prostate tumor cells is reversible: implications for prostate cancer progression. Cancer Research 59 3821-3830.

Cox ME, Deeble PD, Bissonette EA \& Parsons SJ 2000 Activated $3^{\prime}, 5^{\prime}$-cyclic AMP-dependent protein kinase is sufficient to induce neuroendocrine-like differentiation of the LNCaP prostate tumor cell line. Journal of Biological Chemistry 275 13812-13818.

Deeble PD, Murphy DJ, Parsons SJ \& Cox ME 2001 Interleukin-6- and cyclic AMP-mediated signaling potentiates neuroendocrine differentiation of $\mathrm{LNCaP}$ prostate tumor cells. Molecular and Cellular Biology 21 8471-8482.

Diaz M, Abdul M \& Hoosein N 1998 Modulation of neuroendocrine differentiation in prostate cancer by interleukin-1 and -2. Prostate. Supplement 8 32-36.

Drachenberg DE, Elgamal AA, Rowbotham R, Peterson M \& Murphy GP 1999 Circulating levels of interleukin-6 in patients with hormone refractory prostate cancer. Prostate 41 127-133.

Dube N, Cheng A \& Tremblay ML 2004 The role of protein tyrosine phosphatase 1B in Ras signaling. PNAS $\mathbf{1 0 1}$ 1834-1839.

Farini D, Puglianiello A, Mammi C, Siracusa G \& Moretti C 2003 Dual effect of pituitary adenylate cyclase activating polypeptide on prostate tumor LNCaP cells: short- and long-term exposure affect proliferation and neuroendocrine differentiation. Endocrinology 144 1631-1643.

Garabedian EM, Humphrey PA \& Gordon JI 1998 A transgenic mouse model of metastatic prostate cancer originating from neuroendocrine cells. PNAS 95 15382-15387.

Gioeli D, Mandell JW, Petroni GR, Frierson HF Jr \& Weber MJ 1999 Activation of mitogen-activated protein kinase associated with prostate cancer progression. Cancer Research 59 279-284. 
Giri D, Ozen M \& Ittmann M 2001 Interleukin-6 is an autocrine growth factor in human prostate cancer. American Journal of Pathology 159 2159-2165.

Gutierrez-Canas I, Juarranz MG, Collado B, RodriguezHenche N, Chiloeches A, Prieto JC \& Carmena MJ 2005 Vasoactive intestinal peptide induces neuroendocrine differentiation in the $\mathrm{LNCaP}$ prostate cancer cell line through PKA, ERK, and PI3K. Prostate 63 44-55. van Haaften-Day C, Raghavan D, Russell P, Wills EJ, Gregory P, Tilley W \& Horsfall DJ 1987 Xenografted small cell undifferentiated cancer of prostate: possible common origin with prostatic adenocarcinoma. Prostate 11 271-279.

Hirano D, Okada Y, Minei S, Takimoto Y \& Nemoto N 2004 Neuroendocrine differentiation in hormone refractory prostate cancer following androgen deprivation therapy. European Urology 45 586-592.

Huang J, Yao JL, di Sant'Agnese PA, Yang Q, Bourne PA \& $\mathrm{Na}$ Y 2006 Immunohistochemical characterization of neuroendocrine cells in prostate cancer. Prostate 66 1399-1406.

Hudson DL 2004 Epithelial stem cells in human prostate growth and disease. Prostate Cancer and Prostatic Diseases 7 188-194.

Humez S, Monet M, Legrand G, Lepage G, Delcourt P \& Prevarskaya N 2006 Epidermal growth factor-induced neuroendocrine differentiation and apoptotic resistance of androgen-independent human prostate cancer cells. Endocrine-Related Cancer 13 181-195.

Huss WJ, Gregory CW \& Smith GJ 2004 Neuroendocrine cell differentiation in the CWR22 human prostate cancer xenograft: association with tumor cell proliferation prior to recurrence. Prostate 60 91-97.

Ismail AHR, Landry F, Aprikian AG \& Chevalier S 2002 Androgen ablation promotes neuroendocrine cell differentiation in dog and human prostate. Prostate 51 117-125.

Ito T, Yamamoto S, Ohno Y, Namiki K, Aizawa T, Akiyama A \& Tachibana M 2001 Up-regulation of neuroendocrine differentiation in prostate cancer after androgen deprivation therapy, degree and androgen independence. Oncology Reports 8 1221-1224.

Jelbart ME, Russell PJ, Fullerton M, Russell P, Funder J \& Raghavan D 1988 Ectopic hormone production by a prostatic small cell carcinoma xenograft line. Molecular and Cellular Endocrinology 55 167-172.

Jin RJ, Wang Y, Masumori N, Ishii K, Tsukamoto T, Shappell SB, Hayward SW, Kasper S \& Matusik RJ 2004 NE-10 neuroendocrine cancer promotes the LNCaP xenograft growth in castrated mice. Cancer Research 64 5489-5495.

Johnson BE, Whang-Peng J, Naylor SL, Zbar B, Brauch H, Lee E, Simmons A, Russell E, Nam MH \& Gazdar AF 1989 Retention of chromosome 3 in extrapulmonary small cell cancer shown by molecular and cytogenetic studies. Journal of National Cancer Institute $\mathbf{8 1}$ 1223-1228.

Jongsma J, Oomen MH, Noordzij MA, Van Weerden WM, Martens GJ, van der Kwast TH, Schroder FH \& van
Steenbrugge GJ 1999 Kinetics of neuroendocrine differentiation in an androgen-dependent human prostate xenograft model. American Journal of Pathology 154 543-551.

Jongsma J, Oomen MH, Noordzij MA, Van Weerden WM, Martens GJ, van der Kwast TH, Schroder FH \& van Steenbrugge GJ 2000 Androgen deprivation of the PC310 [correction of prohormone convertase-310] human prostate cancer model system induces neuroendocrine differentiation. Cancer Research 60 741-748.

Juarranz MG, Bolanos O, Gutierrez-Canas I, Lerner EA, Robberecht P, Carmena MJ, Prieto JC \& RodriguezHenche N 2001 Neuroendocrine differentiation of the LNCaP prostate cancer cell line maintains the expression and function of VIP and PACAP receptors. Cellular Signalling 13 887-894.

Kaplan-Lefko PJ, Chen TM, Ittmann MM, Barrios RJ, Ayala GE, Huss WJ, Maddison LA, Foster BA \& Greenberg NM 2003 Pathobiology of autochthonous prostate cancer in a pre-clinical transgenic mouse model. Prostate 55 219-237.

Kim CJ, Kushima R, Okada Y \& Seto A 2000 Establishment and characterization of a prostatic small-cell carcinoma cell line (PSK-1) derived from a patient with Klinefelter syndrome. Prostate 42 287-294.

Kim J, Adam RM \& Freeman MR 2002 Activation of the Erk mitogen-activated protein kinase pathway stimulates neuroendocrine differentiation in LNCaP cells independently of cell cycle withdrawal and STAT3 phosphorylation. Cancer Research 62 1549-1554.

Kim J, Adam RM, Solomon KR \& Freeman MR 2004 Involvement of cholesterol-rich lipid rafts in interleukin6-induced neuroendocrine differentiation of LNCaP prostate cancer cells. Endocrinology 145 613-619.

Lee SO, Chun JY, Nadiminty N, Lou W \& Gao AC 2007 Interleukin-6 undergoes transition from growth inhibitor associated with neuroendocrine differentiation to stimulator accompanied by androgen receptor activation during LNCaP prostate cancer cell progression. Prostate 67 764-773.

Liu WK, Ho JC, Qin G \& Che CT $2002 a$ Jolkinolide B induces neuroendocrine differentiation of human prostate $\mathrm{LNCaP}$ cancer cell line. Biochemical Pharmacology 63 951-957.

Liu XH, Kirschenbaum A, Lu M, Yao S, Klausner A, Preston C, Holland JF \& Levine AC 2002b Prostaglandin E(2) stimulates prostatic intraepithelial neoplasia cell growth through activation of the interleukin-6/GP130/STAT-3 signaling pathway. Biochemical and Biophysical Research Communications 290 249-255.

Long RM, Morrissey C, Fitzpatrick JM \& Watson RW 2005 Prostate epithelial cell differentiation and its relevance to the understanding of prostate cancer therapies. Clinical Science 108 1-11.

Mariot P, Vanoverberghe K, Lalevee N, Rossier MF \& Prevarskaya N 2002 Overexpression of an alpha 1H (Cav3.2) T-type calcium channel during neuroendocrine differentiation of human prostate cancer cells. Journal of Biological Chemistry 277 10824-10833. 
Marshall CJ 1995 Specificity of receptor tyrosine kinase signaling: transient versus sustained extracellular signalregulated kinase activation. Cell 80 179-185.

Masumori N, Thomas TZ, Chaurand P, Case T, Paul M, Kasper S, Caprioli RM, Tsukamoto T, Shappell SB \& Matusik RJ 2001 A probasin-large $\mathrm{T}$ antigen transgenic mouse line develops prostate adenocarcinoma and neuroendocrine carcinoma with metastatic potential. Cancer Research 61 2239-2249.

Masumori N, Tsuchiya K, Tu WH, Lee C, Kasper S, Tsukamoto T, Shappell SB \& Matusik RJ 2004 An allograft model of androgen independent prostatic neuroendocrine carcinoma derived from a large probasin promoter-T antigen transgenic mouse line. Journal of Urology 171 439-442.

Mori S, Murakami-Mori K \& Bonavida B 1999 Interleukin-6 induces G1 arrest through induction of p27(Kip1), a cyclin-dependent kinase inhibitor, and neuron-like morphology in LNCaP prostate tumor cells. Biochemical and Biophysical Research Communications 257 609-614.

Oesterling JE, Hauzeur CG \& Farrow GM 1992 Small cell anaplastic carcinoma of the prostate: a clinical, pathological and immunohistological study of 27 patients. Journal of Urology 147 804-807.

Okada H, Shirakawa T, Miyake H, Gotoh A, Fujisawa M, Arakawa S \& Kamidono S 2003 Establishment of a prostatic small-cell carcinoma cell line (SO-MI). Prostate $56231-238$.

Pallen CJ 2003 Protein tyrosine phosphatase alpha (PTPalpha): a Src family kinase activator and mediator of multiple biological effects. Current Topics in Medicinal Chemistry 3 821-835.

Palmer J, Ernst M, Hammacher A \& Hertzog PJ 2005 Constitutive activation of gp130 leads to neuroendocrine differentiation in vitro and in vivo. Prostate 62 282-289.

Perez-Stable C, Altman NH, Mehta PP, Deftos LJ \& Roos BA 1997 Prostate cancer progression, metastasis, and gene expression in transgenic mice. Cancer Research $\mathbf{5 7}$ 900-906.

Pinski J, Wang Q, Quek ML, Cole A, Cooc J, Danenberg K \& Danenberg PV 2006 Genistein-induced neuroendocrine differentiation of prostate cancer cells. Prostate $\mathbf{6 6}$ 1136-1143.

Pinthus JH, Waks T, Schindler DG, Harmelin A, Said JW, Belldegrun A, Ramon J \& Eshhar Z 2000 WISH-PC2: a unique xenograft model of human prostatic small cell carcinoma. Cancer Research 60 6563-6567.

Price DT, Della Rocca G, Guo C, Ballo MS, Schwinn DA \& Luttrell LM 1999 Activation of extracellular signalregulated kinase in human prostate cancer. Journal of Urology 162 1537-1542.

Qiu Y, Robinson D, Pretlow TG \& Kung HJ 1998 Etk/Bmx, a tyrosine kinase with a pleckstrin-homology domain, is an effector of phosphatidylinositol $3^{\prime}$-kinase and is involved in interleukin 6-induced neuroendocrine differentiation of prostate cancer cells. PNAS 95 3644-3649.
Roudier MP, True LD, Higano CS, Vesselle H, Ellis W, Lange P \& Vessella RL 2003 Phenotypic heterogeneity of end-stage prostate carcinoma metastatic to bone. Human Pathology 34 646-653.

di Sant'Agnese PA 1992 Neuroendocrine differentiation in human prostatic carcinoma. Human Pathology 23 287-296.

di Sant'Agnese PA 1998 Neuroendocrine differentiation in prostatic carcinoma: an update. Prostate. Supplement $\mathbf{8}$ 74-79.

di Sant'Agnese PA \& Cockett AT 1996 Neuroendocrine differentiation in prostatic malignancy. Cancer 78 357-361.

Sap J, D'Eustachio P, Givol D \& Schlessinger J 1990 Cloning and expression of a widely expressed receptor tyrosine phosphatase. PNAS 87 6112-6116.

Sauer CG, Roemer A \& Grobholz R 2006 Genetic analysis of neuroendocrine tumor cells in prostatic carcinoma. Prostate 66 227-234.

Schalken JA \& van Leenders G 2003 Cellular and molecular biology of the prostate: stem cell biology. Urology $\mathbf{6 2}$ $11-20$.

Sciarra A, Mariotti G, Gentile V, Voria G, Pastore A, Monti S \& Di Silverio F 2003 Neuroendocrine differentiation in human prostate tissue: is it detectable and treatable? BJU International 91 438-445.

Segal NH, Cohen RJ, Haffejee Z \& Savage N 1994 BCL-2 proto-oncogene expression in prostate cancer and its relationship to the prostatic neuroendocrine cell. Archives of Pathology \& Laboratory Medicine 118 616-618.

Shariat SF, Andrews B, Kattan MW, Kim J, Wheeler TM \& Slawin KM 2001 Plasma levels of interleukin-6 and its soluble receptor are associated with prostate cancer progression and metastasis. Urology 58 1008-1015.

Shen R, Dorai T, Szaboles M, Katz AE, Olsson CA \& Buttyan R 1997 Transdifferentiation of cultured human prostate cancer cells to a neuroendocrine cell phenotype in a hormonedepleted medium. Urologic Oncology 3 67-75.

Siegsmund MJ, Yamazaki H \& Pastan I 1994 Interleukin 6 receptor mRNA in prostate carcinomas and benign prostate hyperplasia. Journal of Urology 151 1396-1399.

Signoretti S, Waltregny D, Dilks J, Isaac B, Lin D, Garraway L, Yang A, Montironi R, McKeon F \& Loda M 2000 p63 is a prostate basal cell marker and is required for prostate development. American Journal of Pathology 157 1769-1775.

Spiotto MT \& Chung TD 2000a STAT3 mediates IL-6induced growth inhibition in the human prostate cancer cell line LNCaP. Prostate 42 88-98.

Spiotto MT \& Chung TD 2000 $b$ STAT3 mediates IL-6induced neuroendocrine differentiation in prostate cancer cells. Prostate 42 186-195.

Stork PJ \& Schmitt JM 2002 Crosstalk between cAMP and MAP kinase signaling in the regulation of cell proliferation. Trends in Cell Biology 12 258-266.

Terry S, Queires L, Gil-Diez-de-Medina S, Chen MW, de la Taille A, Allory Y, Tran PL, Abbou CC, Buttyan R \& 
Vacherot F 2006 Protocadherin-PC promotes androgenindependent prostate cancer cell growth. Prostate 66 1100-1113.

True LD, Buhler K, Quinn J, Williams E, Nelson PS, Clegg N, Macoska JA, Norwood T, Liu A, Ellis W et al. 2002 A neuroendocrine/small cell prostate carcinoma xenograftLuCaP 49. American Journal of Pathology 161 705-715.

Tsai YT, Su YH, Fang SS, Huang TN, Qiu Y, Jou YS, Shih HM, Kung HJ \& Chen RH 2000 Etk, a Btk family tyrosine kinase, mediates cellular transformation by linking Src to STAT3 activation. Molecular and Cellular Biology 20 2043-2054.

Twillie DA, Eisenberger MA, Carducci MA, Hseih WS, Kim WY \& Simons JW 1995 Interleukin-6: a candidate mediator of human prostate cancer morbidity. Urology 45 542-549.

Uchida K, Masumori N, Takahashi A, Itoh N \& Tsukamoto T 2005 Characterization of prostatic neuroendocrine cell line established from neuroendocrine carcinoma of transgenic mouse allograft model. Prostate 62 40-48.

Vanoverberghe K, Vanden Abeele F, Mariot P, Lepage G, Roudbaraki M, Bonnal JL, Mauroy B, Shuba Y, Skryma R \& Prevarskaya N $2004 \mathrm{Ca}^{2+}$ homeostasis and apoptotic resistance of neuroendocrine-differentiated prostate cancer cells. Cell Death and Differentiation 11 321-330.

Vashchenko N \& Abrahamsson PA 2005 Neuroendocrine differentiation in prostate cancer: implications for new treatment modalities. European Urology 47 147-155.

Wang Q, Horiatis D \& Pinski J 2004a Interleukin-6 inhibits the growth of prostate cancer xenografts in mice by the process of neuroendocrine differentiation. International Journal of Cancer 111 508-513.

Wang Q, Horiatis D \& Pinski J $2004 b$ Inhibitory effect of IL6 -induced neuroendocrine cells on prostate cancer cell proliferation. Prostate 61 253-259.

Wojno KJ \& Epstein JI 1995 The utility of basal cell-specific anti-cytokeratin antibody (34 beta E12) in the diagnosis of prostate cancer. A review of 228 cases. American Journal of Surgical Pathology 19 251-260.

Wright ME, Tsai MJ \& Aebersold R 2003 Androgen receptor represses the neuroendocrine transdifferentiation process in prostate cancer cells. Molecular Endocrinology 17 1726-1737.

Wu C \& Huang J 2007 Phosphatidylinositol 3-kinaseAKT-mammalian target of rapamycin pathway is essential for neuroendocrine differentiation of prostate cancer. Journal of Biological Chemistry 282 3571-3583.

Wu C, Zhang L, Bourne PA, Reeder JE, di Sant'Agnese PA, Yao JL, Na Y \& Huang J 2006 Protein tyrosine phosphatase PTP1B is involved in neuroendocrine differentiation of prostate cancer. Prostate $\mathbf{6 6}$ 1125-1135.
Xing N, Qian J, Bostwick D, Bergstralh E \& Young CY 2001 Neuroendocrine cells in human prostate overexpress the anti-apoptosis protein survivin. Prostate 48 7-15.

Xue Y, Verhofstad A, Lange W, Smedts F, Debruyne F, de la Rosette J \& Schalken J 1997 Prostatic neuroendocrine cells have a unique keratin expression pattern and do not express Bcl-2: cell kinetic features of neuroendocrine cells in the human prostate. American Journal of Pathology 151 1759-1765.

Yang X, Chen MW, Terry S, Vacherot F, Chopin DK, Bemis DL, Kitajewski J, Benson MC, Guo Y \& Buttyan R 2005 A human- and male-specific protocadherin that acts through the wnt signaling pathway to induce neuroendocrine transdifferentiation of prostate cancer cells. Cancer Research 65 5263-5271.

Yao JL, Madeb R, Bourne P, Lei J, Yang X, Tickoo S, Liu Z, Tan D, Cheng L, Hatem F et al. 2006 Small cell carcinoma of the prostate: an immunohistochemical study. American Journal of Surgical Pathology 30 705-712.

Yuan TC, Veeramani S, Lin FF, Kondrikou D, Zelivianski S, Igawa T, Karan D, Batra SK \& Lin MF 2006 Androgen deprivation induces human prostate epithelial neuroendocrine differentiation of androgensensitive LNCaP cells. Endocrine-Related Cancer 13 151-167.

Zelivianski S, Dean J, Madhavan D, Lin FF \& Lin MF 2000 Expression of receptor protein tyrosine phosphatase alpha mRNA in human prostate cancer cell lines. Molecular and Cellular Biochemistry 208 11-18.

Zelivianski S, Verni M, Moore C, Kondrikov D, Taylor R \& Lin MF 2001 Multipathways for transdifferentiation of human prostate cancer cells into neuroendocrine-like phenotype. Biochimica et Biophysica Acta 1539 28-43.

Zhang XQ, Kondrikov D, Yuan TC, Lin FF, Hansen J \& Lin MF 2003 Receptor protein tyrosine phosphatase alpha signaling is involved in androgen depletion-induced neuroendocrine differentiation of androgen-sensitive LNCaP human prostate cancer cells. Oncogene 22 6704-6716.

Zhou Z, Flesken-Nikitin A, Corney DC, Wang W, Goodrich DW, Roy-Burman P \& Nikitin AY 2006 Synergy of p53 and $\mathrm{Rb}$ deficiency in a conditional mouse model for metastatic prostate cancer. Cancer Research $\mathbf{6 6}$ 7889-7898.

Zi X \& Agarwal R 1999 Silibinin decreases prostatespecific antigen with cell growth inhibition via G1 arrest, leading to differentiation of prostate carcinoma cells: implications for prostate cancer intervention. PNAS 96 7490-7495. 